\title{
A Research on the Science and Engineering students' College English Learning Behavior from the Perspective of Constructivism Learning Theory
}

\author{
-- Based on the "Outstanding Program" \\ Liu Jiajia \\ Department of Foreign Language Anhui Polytechnic University, Anhui Province, China \\ Linda9896@126.com
}

\begin{abstract}
This paper analyzes the curricular and extracurricular English learning behaviors of 243 science and engineering students, and then makes a description of their learning behavior patterns: the students' curricular learning behavior is static, extracurricular learning behavior is passive, and extracurricular communicative act is a one-way street exchange, which is unable to adapt to the requirements of China's higher education reform. Based on the constructivism learning theory, the paper proposes some suggestions for English teaching reform as per the "Outstanding Program": 1) Creating a new teaching mode and a new curriculum system to adapt to the "Outstanding Program". 2) Making full use of modern teaching facilities and optimizing network classroom. 3) Improving the faculty quality and being an "outstanding teacher". 4) Encouraging students to participate in social services and service practice to enhance collaborative learning.
\end{abstract}

Index Terms - constructivism, English learning behavior, outstanding program

\section{Constructivism Learning Theory}

Constructivism theory firstly proposed by the Swiss philosopher and psychologist Jean Piaget is the further development of the cognitive theory. The "Piaget School" which was created by him was the most influential one in the field of cognitive development. Later, many psychologists and educators, such as Kohlberg and Vygotsky, enriched and developed the constructivism theory, making it a complete learning theory.

Constructivism holds that knowledge is not taught by teachers, but got by learners via meaning construction in certain socio-cultural context, with the help of other aids or other persons and necessary learning materials. And it considers "situation", "collaboration", "conversation" and "meaning construction" are the four elements of the learning environment [1]. Constructivism teaching principles can be summarized as follows [1]: 1) stresses student-centered setting; 2) stresses the importance of "situation" in the meaning construction; 3) stresses the importance of "collaborative learning"; 4) stresses learning environment design; 5) stresses that students learn by a variety of information resources; 6) stresses that the ultimate goal of learning process is to complete the meaning construction (rather than teaching objectives). In addition, constructivism learning is a social, interactive collaborative learning [2]. In accordance with the theory, the students could construct "meaning" to acquire knowledge in the "scene" under the "collaboration" and "conversation" in between teachers or peers. By this way, the students in learning activities are more "initiative, purposive, authentic, constructive" and "cooperative" [3].

In 2004 [4] and 2007 [5], the Ministry of Education issued the draft and revised version of the College English Teaching Requirements. Ref. [5] has two new breakthroughs in terms of content. One is that paying more attention to students' integrated application capabilities; the other is that changing teaching mode to be student-oriented and computerbased multimedia one. English teaching programs, however, still maintain traditional mode, which is not conducive to students' independent learning. Therefore, we should carefully explore new teaching methods under the guidance of constructivism learning theory.

\section{The Program for Educating and Training Outstanding Engineers}

"The Program for Educating and Training Outstanding Engineers" (hereinafter referred to as "Outstanding Program") proposed by Seventeenth Party Congress [6], whose main goal is to train a large number of high-quality engineering talents with innovative abilities to enhance Chinese students' competitiveness and improve China comprehensive national strength.

Some engineering students are found high in marks but poor in abilities in traditional teaching mode that ignores their English application abilities training. The current situation of English teaching to some extent might hinder their development in carrying out engineering practices and academic exchanges in the international stage. Therefore, understanding the characteristics of these type learners is very useful to guide the English teaching as well as providing reference data for the "Outstanding Program".

\section{Survey Design}

\section{A. Survey Object}

The objects of the survey are 260 freshmen and sophomores from Colleges of Computer and Information, Electrical Engineering, Management Engineering, and Civil Engineering and Architecture. 


\section{B. The Survey Form}

The survey form is a questionnaire referring to the one in the paper "A Study on the Foreign Language Learning Behavior of Science and Engineering Students" published in "Foreign Languages Teaching" [7] to ensure the reliability and validity. The questionnaire consists of three parts with 15 questions involving students in the curricular learning behavior, extra-curricular learning behavior and extracurricular communicative acts. The survey randomly distributed 260 copies, of which 250 copies are returned and 243 are valid. It represents a $96.0 \%$ response rate and a $97.0 \%$ valid rate.

\section{An analysis of the Findings of the Survey}

\section{A. Curricular learning behavior (see Table 1)}

From Table 1:

About $64.6 \%$ of the students never take initiative to ask the teacher any questions, and the highest proportion in the other items is "sometimes" option rather than "often" and for the item "consulting notes and reference materials", "never" option is up to $29.6 \%$. From the data, a lot of students seem to lack self-discipline. And most of them are accustomed to passive transmission learning whereas teachers are used to the "teacher-centered" philosophy. The students' knowledge acquisition is very mechanical in such a mode resulting in weak interaction between teachers and students.

Table 1

\begin{tabular}{|c|c|c|}
\hline Items & Optional Choices & $\begin{array}{l}\text { Number } \\
\text { (percentage) }\end{array}$ \\
\hline \multirow{3}{*}{ Taking notes in class } & a often & $75(30.9 \%)$ \\
\hline & b sometimes & $145(59.7 \%)$ \\
\hline & c never & $23(9.5 \%)$ \\
\hline \multirow{3}{*}{$\begin{array}{l}\text { Initiative to speak in } \\
\text { class, answer teachers' } \\
\text { questions }\end{array}$} & a often & $91(37.4 \%)$ \\
\hline & b sometimes & $127(52.3 \%)$ \\
\hline & c never & $25(10.3 \%)$ \\
\hline \multirow{3}{*}{$\begin{array}{l}\text { Consulting notes and } \\
\text { reference materials }\end{array}$} & a often & $73(30.0 \%)$ \\
\hline & b sometimes & $98(40.3 \%)$ \\
\hline & c never & $72(29.6 \%)$ \\
\hline \multirow{3}{*}{$\begin{array}{l}\text { Initiative to ask teachers } \\
\text { if have a problem }\end{array}$} & a often & $25(10.3 \%)$ \\
\hline & b sometimes & $61(25.1 \%)$ \\
\hline & c never & $157(64.6 \%)$ \\
\hline \multirow{3}{*}{$\begin{array}{l}\text { Participating in language } \\
\text { exchange activities in } \\
\text { classroom }\end{array}$} & a often & $97(39.9 \%)$ \\
\hline & b sometimes & $115(47.3 \%)$ \\
\hline & c never & $31(12.8 \%)$ \\
\hline
\end{tabular}

\section{B: Extra-curricular learning behavior (see Table 2)}

From Table 2:

1) Only $20.2 \%$ of the students "often" preview the text, and $54.3 \%$ of the students "never" preview, awaiting teachers to explain completely. It is difficult to enter teacher-led verbal communication activities owing to no previewing. And it also shows classroom learning is the principal way for most students to learn English.

Table 2

\begin{tabular}{|c|c|c|}
\hline Items & Optional Choices & $\begin{array}{l}\text { Number } \\
\text { (percentage) }\end{array}$ \\
\hline \multirow{3}{*}{ Previewing the text } & a. often & $49(20.2 \%)$ \\
\hline & b. sometimes & $62(25.5 \%)$ \\
\hline & c. never & $132(54.3 \%)$ \\
\hline \multirow{3}{*}{ Finishing homework } & $\begin{array}{l}\text { a. to finish on time } \\
\text { independently }\end{array}$ & $23(9.5 \%)$ \\
\hline & $\begin{array}{l}\text { b. to finish on time } \\
\text { by consulting }\end{array}$ & $195(80.2 \%)$ \\
\hline & $\begin{array}{l}\text { c. to plagiarize for } \\
\text { marks }\end{array}$ & $25(10.3 \%)$ \\
\hline \multirow{3}{*}{$\begin{array}{l}\text { Reading English } \\
\text { newspapers and magazines }\end{array}$} & a. often & $10(4.1 \%)$ \\
\hline & b. sometimes & $145(59.7 \%)$ \\
\hline & c. never & $88(36.2 \%)$ \\
\hline \multirow{3}{*}{$\begin{array}{l}\text { Listening to English radio, } \\
\text { recording or watching } \\
\text { English TV programs }\end{array}$} & a. often & $9(3.7 \%)$ \\
\hline & b. sometimes & $133(54.7 \%)$ \\
\hline & c. never & $101(41.6 \%)$ \\
\hline \multirow{3}{*}{$\begin{array}{l}\text { Using network to learn } \\
\text { English or communicate in } \\
\text { English }\end{array}$} & a. to learn English & $29(11.9 \%)$ \\
\hline & $\begin{array}{l}\text { b. to watch English } \\
\text { movies }\end{array}$ & $131(53.9 \%)$ \\
\hline & $\begin{array}{l}\text { c. to finish English } \\
\text { assignment }\end{array}$ & $83(34.2 \%)$ \\
\hline
\end{tabular}

2) For items "Reading English newspapers and magazines", and "Listening to English radio, recording or watching English TV programs", "sometimes" accounts for about a half, which shows these commonly used extra-curricular learning tools are still the first choices for students to learn English, but we also can not ignore "never" option in the two items accounts for $36.2 \%$ and $41.6 \%$.

3) The ratio of the item "using network to watch movies" is $53.9 \%$, "to learn English" accounts for only $11.9 \%$, and "to finish English assignment" is $34.2 \%$. In the science and engineering universities, students are frequently exposed to English on the computers. Unfortunately, computer mostly plays a role of entertainment - watching English movies, indicating most students are used to adhering to the teachers' arrangements with a clear purpose while they value less information input in extracurricular time. Table 2 tells some students just learn English because of external force, which is described as "instrumental" motivation by Gardner [8].

\section{C. xtra-curricular communicative acts (see Table 3)}

From Table 3:

1) "Often" option accounts for $74.9 \%$ in the item "Attending English lectures", indicating that a variety of English lectures are very good extra-curricular language exchange activities, which should be promoted further. 
Table 3

\begin{tabular}{|c|c|c|}
\hline Items & Optional Choices & $\begin{array}{l}\text { Number } \\
\text { (percentage) }\end{array}$ \\
\hline \multirow{3}{*}{$\begin{array}{l}\text { Attending English } \\
\text { lectures }\end{array}$} & a. often & $182(74.9 \%)$ \\
\hline & b. sometimes & $48(19.8 \%)$ \\
\hline & c. never & $13(5.3 \%)$ \\
\hline \multirow{3}{*}{$\begin{array}{l}\text { Communicating } \\
\text { with teachers and } \\
\text { classmates in } \\
\text { English }\end{array}$} & a often & $6(2.5 \%)$ \\
\hline & b. sometimes & $\begin{array}{l}114 \\
(46.9 \%)\end{array}$ \\
\hline & c. never & $123(50.6 \%)$ \\
\hline \multirow{3}{*}{$\begin{array}{l}\text { Participating in a } \\
\text { variety of English } \\
\text { Contests }\end{array}$} & $\begin{array}{l}\text { a. To participate and the } \\
\text { award-winning }\end{array}$ & $72(3.0 \%)$ \\
\hline & $\begin{array}{l}\text { b. Willing to participate but } \\
\text { often hesitate }\end{array}$ & $145(59.7 \%)$ \\
\hline & c. Unwilling to participate in & $26(10.7 \%)$ \\
\hline \multirow{3}{*}{$\begin{array}{l}\text { Participating in } \\
\text { the English } \\
\text { Corner }\end{array}$} & a. often & $4(1.6 \%)$ \\
\hline & b. sometimes & $72(29.6 \%)$ \\
\hline & c. never & $167(68.7 \%)$ \\
\hline \multirow{3}{*}{$\begin{array}{l}\text { Communicating } \\
\text { with foreign } \\
\text { teachers }\end{array}$} & a. often & $14(5.8 \%)$ \\
\hline & b. sometimes & $17(7.0 \%)$ \\
\hline & c. never & $212(87.2 \%)$ \\
\hline
\end{tabular}

2) "Willing to participate but often hesitate" accounts for $59.7 \%$, indicating that a considerable part of students want to participate in extra-curricular communication activities, but lack confidence due to the impact of traditional ideas and teaching mode.

3) $68.7 \%$ of the students "never" participate in the English corner, where foreign teachers join every week in my university. The proportion also indirectly leads to the high ration $87.2 \%$ in the item "never communicating with foreign teachers". The teachers should help students change their learning motivation in order to develop their all-around qualities.

\section{Suggestions for college English teaching reform}

Despite the small sample size, the results of the survey to some degree reflect the status quo of science and engineering college students' English learning behavior. Therefore, we need a new round reform based on the "Outstanding Program" in order to train more talents in line with the needs of the community.

\section{A. Creating a new teaching mode and curriculum system to adapt to the "Outstanding Program".}

The analysis of the survey shows that college English teaching needs a new philosophy as an instruction to innovate the traditional one. Ref. [9] thinks learning is not a simple process of information input, storage and retrieval, and also not a simple information accumulation. Learners must be involved in the process to construct knowledge by consultation, conversation, and communication with others.
The "Outstanding Program" gives emphasis on improving the overall qualities of training talents, in which the humanities is a very important part. Therefore, the curriculum system should possess both humanities and instrumental traits to strengthen the practical aspects, such as requiring students to write feedback after watching English movies, etc.

\section{B. Making full use of modern teaching facilities and optimizing network classroom.}

The network classroom aims to realize the communication between teachers and students through image, sound, graphics and words with the help of network media [10]. On the one hand, the students are not subject to external constraints in network learning, on the other hand, the increasing information and the vision expansion brought by internet would extend the students' knowledge grasp. According to such a new teaching mode, students would become actively "require to learn" from passively "required to learn" [11].

From Table 1, the traditional classroom looks like a "oneman show" for teachers, on the contrary, the communication based on multimedia network eliminates the constraints of time and space, achieving multi-subject [12]. Combining network technology with learning content, students individually or collectively construct knowledge with the help of teachers, that is, they collaboratively complete the teaching process [13].

\section{Improving the faculty quality and being an "outstanding teacher".}

The implementation of the new teaching mode and curriculum system put forward higher requirements for teachers. Constructivism learning theory suggests that knowledge is not taught by teachers, but learners in a certain cultural context, with the help of others or necessary learning materials, obtain via meaning construction, in which "meaning construction" is the ultimate goal of the whole learning process [14].

Table 2 and Table 3 also show many students want to participate in practical communication activities to improve their English skills. Teachers should provide students with authentic learning environment by well-designed classroom discussions and group activities what students are interested in. Ref. [15] says, more closely the context relates to the real world, the students are more likely to take advantage of their abilities to solve problems. Teachers should always be a helper, facilitator, consultant, and negotiator to provide timely guidance, encouragement, and help in students' acquiring knowledge in order to establish a good relationship between them and students. [16].

Table 3 shows that $59.7 \%$ students are willing to participate in the English competition but hesitant due to lack of confidence. Teachers should actively organize activities out of English classrooms, by which to improve students' language proficiency and enhance students' cross-cultural communication abilities. 


\section{Encouraging students to participate in social services and service practice to enhance collaborative learning.}

The three tables show that students' curricular learning behavior is much more static, extracurricular learning behavior is rather passive, and extracurricular communicative act is relatively one-way street exchange. Constructivism holds that the knowledge construction happens in social interaction, in which collaboration is an effective way for learning. Since school-enterprise cooperation is the key and core of the "Outstanding Program", Universities and local enterprises can cooperatively build a platform that they both should share training tasks with clear rights and obligations to explore new training style in double subjects.

\section{Conclusion}

In contrast to the traditional teaching methods, constructivism learning theory truly reflects the "teacher-led" and "student-centered" philosophy, by which we can direct English teaching reform. As we all know, the final results of foreign language teaching, regardless of any purposes, no matter what kind of teaching methods employed, should be reflected in the learners [17].

The "Outstanding Program" is an important measure towards strengthening a powerful country in education for China. The English teaching of Science and Engineering college students should comply with the "Outstanding Program" to further reorganize curriculum system and strengthen the students' practical creative abilities to meet common and industrial standards. Besides, all the issues implemented should not only adapt to economic and social development of the nation, but fit into industrial restructuring of local provinces.

\section{References}

[1] H. Kekang, "Constructivism - theoretical basis of innovating traditional instruction," Beijing: China Central Radio and TV University Press, 1998.
[2] L. S. Vygotsky, "Mind in Society" Cambridge, MA: Harvard University Press, 1978.

[3] L. Lin-Lin, and G. Peng, "An Autonomous Learning Research under the Mode of the Network Foreign Language Self-study", Foreign Language Education, pp. 68-721, Dec 2007.

[4] "College English Curriculum Requirements (for trial implementation)", The General Office of the Ministry of Education, 2004.

[5] "College English Curriculum Requirements", The General Office of the Ministry of Education, 2007.

[6] "A Number of Opinions on the implementation of the Program for Educating and Training Outstanding Engineers", Ministry of Education of the People's Republic of China, 2011.

[7] L. Lisheng, H. Fusheng, and Y. Fang, "A Study on the Foreign Language Learning Behavior of Science and Engineering Students", Foreign Language Teaching, pp. 31 - 33 Sep 2001.

[8] R. C. Gardner, "Social Psychology and Second Language Learning", Edward Arnold, 1985.

[9] G. Wen, X. Binyan, and Wu Gang, "Constructivist Education", Beijing: Education Science Press, 2008.

[10] Y. Shengquan, "The Design and Development of Network Curriculum" Beijing: Beijing Normal University Press, 2007.

[11] L. Runqing, "the development trend of the Foreign Language Teaching and Research", Foreign Language Teaching and Research, Vol. 1, 1999.

[12] S. Xinmin, "Theory of the College Students Learning Ability Training in Multimedia and Network Environment-Summary Report", China Remote Education, Vol. 11, 2001.

[13] F. C. Lunnenberg, "Constructivism and Technology Instructional Design for Successful Education Reform, Journal of Instructional Psychology, Vol. 2, pp. 75-81, 1998.

[14] F. Lin and Z. Qiyun, "The Constructivism Teaching Theory and the English Reformation, Foreign Language Teaching, Vol. 4, pp. 28-321, 2003.

[15] D.J. Cunningham , "Assessing Constructions and Construction Assessments : A Dialogue", Hillsdale, NJ : Lawrence Erlbaum Associates , pp. 134, 1992.

[16] I. Lee, "Supporting Great Autonomy in Language Learning", ELT J, Vol. 4, pp. 282-289, 1998.

[17] S. Dingfang and Z. zhixiang, "Modern Foreign Language Teaching Theory, Practice and Methods", Shanghai: Shanghai Foreign Language Education Press, 1996.Alpha 